\title{
Lethal and growth inhibitory activities of Neotropical Annonaceae-derived extracts, commercial formulation, and an isolated acetogenin against Helicoverpa armigera
}

\author{
Camila M. Souza ${ }^{1}$ Edson L. L. Baldin ${ }^{1} \cdot$ Leandro P. Ribeiro $^{2} \cdot$ Ivana F. Silva $^{1}$ • \\ Rafaela Morando $^{1} \cdot$ Keylla U. Bicalho ${ }^{3} \cdot$ José D. Vendramim $^{4} \cdot$ João B. Fernandes ${ }^{3}$
}

Received: 21 June 2016/Revised: 2 November 2016/Accepted: 16 November 2016/Published online: 10 December 2016 (c) Springer-Verlag Berlin Heidelberg 2016

\begin{abstract}
Among tropical plant families, members of Annonaceae have great potential as a source of biopesticides. To develop an alternative tool for control of Helicoverpa armigera, efficacy of ethanolic extracts from seeds of five species belonging to the genus Annona (A. montana Macfad., A. mucosa Jacq., A. muricata L., A. reticulata L. and A. sylvatica A. St.-Hil.) and an acetogenin-based commercial bioinsecticide (Anosom ${ }^{\circledR} 1 \mathrm{EC}, 10,000 \mathrm{ppm}$ of annonin as the main active ingredient) were evaluated in a dietary exposure bioassays. In an initial screening, an ethanolic extract from A. mucosa seeds $\left(\mathrm{LC}_{50}=1479 \mathrm{ppm}\right)$ and Anosom $^{\circledR} 1$ EC $\left(\mathrm{LC}_{50}=1151 \mathrm{ppm}\right)$ were the most promising treatments. In addition to acute toxicity, pronounced inhibition of $H$. armigera larval growth was observed in both treatments. Using chromatographic techniques, bioguided fractionations were conducted and the acetogenin bis-tetrahydrofuran rolliniastatin-1 was isolated as the primary compound from the most active fractions of $A$.
\end{abstract}

Communicated by M.B. Isman.

Camila M. Souza

souza_767@hotmail.com

1 Department of Crop Protection, College of Agricultural Sciences, São Paulo State University (FCA/UNESP), José Barbosa de Barros street, 1780, Botucatu,

São Paulo 18.610-307, Brazil

2 Research Center for Family Agriculture, Agricultural Research and Rural Extension Company of Santa Catarina (CEPAF/EPAGRI), Chapecó, Santa Catarina, Brazil

3 Department of Chemistry, Federal University of São Carlos (UFSCar), São Carlos, São Paulo, Brazil

4 Department of Entomology and Acarology, "Luiz de Queiroz" College of Agriculture, University of São Paulo (ESALQ/USP), Piracicaba, São Paulo, Brazil mucosa. At a concentration of $41.55 \mathrm{ppm}$, rolliniastatin-1 caused total mortality of $H$. armigera larvae after the fourth day of exposure. In greenhouse trials, extract of A. mucosa (as an emulsifiable concentrate formulation) and the botanical insecticide based on extract of Annona squamosa L. (Anosom ${ }^{\circledR} 1 \mathrm{EC}$ ), both at $\mathrm{LC}_{90}$ values previously estimated, were compared with a diamide-based commercial insecticide (flubendiamide $480 \mathrm{SC}$ ) for mortality after $168 \mathrm{~h}$ of exposure to larvae on tomato plants; all treatments caused high larval mortality ( $>90 \%$ ). Thus, the results of this study indicate that the derivatives of Annonaceae are a useful alternative for the integrated management of $H$. armigera.

Keywords Annonaceae - Acetogenin - Botanical insecticides · Old world bollworm - Rolliniastatin-1 . Chromatographic techniques

\section{Key message}

- Annonaceae species were screened to detect sources of insecticidal compounds.

- An ethanolic extract from A. mucosa seeds caused strong mortality to Helicoverpa armigera.

- The major compound present is the acetogenin bistetrahydrofuran rolliniastatin-1.

- Ethanolic extract from A. mucosa seeds also caused high larval mortality in greenhouse trial.

\section{Introduction}

Helicoverpa armigera (Hübner, 1808) (Lepidoptera: Noctuidae) is a polyphagous pest species whose larvae damage vegetative and reproductive structures of several crops 
(Lammers and Macleod 2007) in Africa, Asia, Oceania and Europe (Venette et al. 2003), and more recently in South America (Czepak et al. 2013; Murúa et al. 2014). The global agricultural production losses caused by $H$. armigera may approach USD 5 billion annually, and in China and India, an estimated $50 \%$ of pesticide use is for control of this pest (Lammers and Macleod 2007). The first records of $H$. armigera in Brazil were on soybean in Bahia and cotton in Mato Grosso during the 2012/2013 harvests (Czepak et al. 2013). Currently, this pest is widespread throughout Brazil, attacking cotton, soybean, corn, millet, tomato, wheat (Czepak et al. 2013), citrus (Bueno et al. 2014) and forage crops (Bueno and Sosa-Gómez 2014).

In Brazil, chemical control with synthetic insecticides is the primary method for management of $H$. armigera; however, most of the insecticides used for its control are registered for emergency use (Czepak et al. 2013). Furthermore, $H$. armigera has many documented cases of resistance to insecticides, including pyrethroids, organophosphates, carbamates, organochlorines (Jouben et al. 2012), spinosins (Aheer et al. 2009) and toxins derived from Bacillus thuringiensis (Zhang et al. 2011; Yang et al. 2013); thus, the motivation for studies to identify alternative pest control methods is provided.

The use of plants with insecticidal activity can be an effective strategy as part of an integrated pest management program, also in most of cases these compounds have low toxicity to mammals and non-target organisms and low persistence in the environment; their use is environmentally sound (Cloyd 2004; Isman 2006). Moreover, plants with insecticidal activity constitute an important option for pest management in organic food production systems in which synthetic compounds are not permitted (Zanardi et al. 2015).

Among tropical plant families, the Annonaceae has great potential as a source of biopesticides and has been highlighted from plant systematics in the last decades (Isman 2006; Isman and Seffrin 2014). The family includes 135 genera and approximately 2500 described species to date, with most occurring in the pantropical region (Chatrou et al. 2004). Among the classes of bioactive compounds found in Annonaceae, the acetogenins have attracted attention since the 1980s because the structural characteristics that promote a wide range of biological activities, including potent insecticidal action (Ocampo and Ocampo 2006). Acetogenins are a series of natural products (C-35/C-37) derived from long-chain fatty acids combined with a unit of 2-propanol (Alali et al. 1999). These molecules are potent inhibitors of complex I (NADH: ubiquinone oxidoreductase) of the mitochondrial electron-transport system and of the coenzyme NADH in the cell membranes of target arthropods (Lewis et al. 1993).
In recent research, the derivatives of Annonaceae were effective against different pest species of agricultural importance, including Plutella xylostella L. (Leatemia and Isman 2004; Trindade et al. 2006), Trichoplusia ni Hübner and Myzus persicae (Sulzer) (Ribeiro et al. 2014a), Panonychus citri (McGregor) (Ribeiro et al. 2014b), Spodoptera frugiperda (JE Smith) (Blessing et al. 2010; Tolosa et al. 2014; Ansante et al. 2015a), Diaphorina citri Kuwayama (Ribeiro et al. 2015) and coleopteran stored grains pests (Ribeiro et al. 2013, 2014c; Gonçalves et al. 2015). However, until this study, the effectiveness of extracts of Neotropical Annonaceae on $H$. armigera has not been examined. Thus, in this study, first, the bioactivity of seed ethanol-extracts from five species of Annona ( $A$. mucosa, A. muricata, A. montana, A. reticulata and $A$. sylvatica) and the acetogenin-based commercial bioinsecticide [Anosom ${ }^{\circledR} 1$ EC (Agrilife SOM Phytopharma Ltd., Hyderabad, Andhra Pradesh State, India)] was evaluated on $H$. armigera in laboratory bioassays. Second, bioguided fractionation was conducted to isolate the primary acetogenin of the most promising extract, which was evaluated for the toxicity on $H$. armigera. Finally, the efficacy of the most promising extract (as an emulsifiable concentrate formulation) was compared with that of acetogenin-based and synthetic-based commercial insecticides for the control of $H$. armigera on tomato plants in a greenhouse trial.

\section{Materials and methods}

\section{Plant material and preparation of plant extracts}

Voucher specimens of the species used in this study (Table 1), previously identified by Prof. Dr. Renato MelloSilva [Department of Botany, Biosciences Institute/ University of São Paulo (IB/USP)], were deposited in the herbarium of the Department of Biological Sciences at "Luiz de Queiroz" College of Agriculture/University of São Paulo in Piracicaba municipality, São Paulo State, Brazil.

To prepare the extracts, seeds collected from ripe fruit were dried in a forced-air oven at $40{ }^{\circ} \mathrm{C}$ for $48-72 \mathrm{~h}$. The dried seeds were ground in a Wiley mill to a fine powder, which were stored in sealed glass in a domestic freezer $\left(-10{ }^{\circ} \mathrm{C}\right)$ until use.

The organic extracts were obtained by maceration in solvent ethanol (at the ratio of 1:5 w/v). The powder and solvent stood in hermetically sealed flasks for three days, followed by filtration with filter paper. The process of soaking in ethanol was repeated three times for each sample. The remaining solvent in the filtered solution was eliminated in a rotaevaporator at $50{ }^{\circ} \mathrm{C}$ and a pressure of $-600 \mathrm{mmHg}$. After complete solvent evaporation in an 
Table 1 Collection data for the species of Annonaceae used in the study

\begin{tabular}{|c|c|c|c|}
\hline Species & Collection site & Collection date & Voucher \\
\hline Annona montana Macfadyen & $\begin{array}{l}\text { ESALQ/USP Campus, Piracicaba, SP, Brazil }\left(22^{\circ} 42^{\prime} 28,2^{\prime \prime} \mathrm{S} \text {; }\right. \\
\left.\quad 47^{\circ} 37^{\prime} 59,4^{\prime \prime} \mathrm{W} \text {; elevation: } 537 \mathrm{~m}\right)\end{array}$ & $21 / 03 / 11$ & 121,203 \\
\hline Annona тисоsa Jacquin & $\begin{array}{l}\text { ESALQ/USP Campus, Piracicaba, SP, Brazil }\left(22^{\circ} 42^{\prime} 28,5^{\prime \prime} \mathrm{S} \text {; }\right. \\
\left.47^{\circ} 37^{\prime} 59,6^{\prime \prime} \mathrm{W} \text {; elevation: } 534 \mathrm{~m}\right)\end{array}$ & $17 / 03 / 11$ & 120,985 \\
\hline Annona muricata Linnaeus & $\begin{array}{l}\text { ESALQ/USP Campus, Piracicaba, SP, Brazil }\left(22^{\circ} 42^{\prime} 25,4^{\prime \prime} \mathrm{S} \text {; }\right. \\
\left.47^{\circ} 37^{\prime} 43,9^{\prime \prime} \mathrm{W} \text {; elevation: } 576 \mathrm{~m}\right)\end{array}$ & $12 / 04 / 11$ & 121,892 \\
\hline Annona reticulata Linnaeus & $\begin{array}{l}\text { São Luís Farmer, Descalvado, SP, Brazil }\left(21^{\circ} 52^{\prime} 58,0^{\prime \prime} \mathrm{S} \text {; }\right. \\
\left.47^{\circ} 40^{\prime} 38,0^{\prime \prime} \mathrm{W} \text {; elevation: } 679 \mathrm{~m}\right)\end{array}$ & $02 / 04 / 11$ & 123,318 \\
\hline Annona sylvatica A. St.-Hil. & $\begin{array}{l}\text { Emilio Falcão Avenue, Erval Seco, RS, Brazil }\left(27^{\circ} 25^{\prime} 41,8^{\prime \prime} \mathrm{S} \text {; }\right. \\
\left.53^{\circ} 34^{\prime} 11,2^{\prime \prime} \mathrm{W} \text {; elevation: } 466 \mathrm{~m}\right)\end{array}$ & $25 / 04 / 11$ & 121,205 \\
\hline
\end{tabular}

airflow chamber, extraction yield was determined for the seeds of each species.

\section{Test insects}

The colony of $H$. armigera used in the bioassays was established from adults collected in soybean and corn crops in the state of São Paulo, Brazil. Dr. Alexander Specht (Embrapa Cerrado, Brasilia, DF, Brazil) previously identified the species using morphological and molecular characters described in the protocol proposed by Specht et al. (2013).

Stock rearing of $H$. armigera was kept under controlled laboratory conditions (temperature: $25 \pm 2{ }^{\circ} \mathrm{C}$; $\mathrm{RH}$ : $60 \pm 10 \%$; photoperiod: $14 \mathrm{~L}: 10 \mathrm{D} \mathrm{h}$ ), with the caterpillars fed on an artificial diet (Greene et al. 1976). Adults were fed honey water solution $10 \%$ (w/v). Reproduction of $H$. armigera was conducted following the protocols of Kao (1995) and Jah et al. (2012).

\section{Bioassays}

The laboratory tests were conducted under controlled conditions (temperature: $25 \pm 2{ }^{\circ} \mathrm{C}$; RH: $60 \pm 10 \%$; photoperiod: $14 \mathrm{~L}: 10 \mathrm{D} \mathrm{h}$ ), whereas the greenhouse trial (average temperature: $24.3^{\circ} \mathrm{C}$, with a maximum of $25.6^{\circ} \mathrm{C}$ and a minimum of $16.7{ }^{\circ} \mathrm{C}$; average $\mathrm{RH}$ : $58 \%$, with a maximum of $95 \%$ and a minimum of $38 \%$; natural light) was conducted during June 2015 in Botucatu, SP, Brazil.

\section{Screening of Annona seed extracts in the laboratory}

To identify the most promising species for control of $H$. armigera, preliminary tests with ethanolic seed extracts prepared from five species Annona (A. muricata, A. mucosa, A. reticulata, A. sylvatica and A. montana) and an acetogenin-based commercial bioinsecticide (Anosom ${ }^{\circledR} 1$ EC) were conducted. The extracts were solubilized in a mixture of acetone/methanol (1:1 v/v) and added $5 \mathrm{~mL}$ per
$300 \mathrm{~g}$ of diet as described by Ansante et al. (2015). Anosom $^{\circledR}$ was dissolved in distilled water and added to the diet at identical proportion as that for the extracts.

The treatments were incorporated into artificial diet (Greene et al. 1976) at concentration of 2000 ppm (diagnostic concentration). As negative controls, we used deionized water and the solvent solution [acetone/methanol $(1: 1, \mathrm{v} / \mathrm{v})]$, which were used to solubilize the biopesticide and extracts, respectively, at identical proportions.

Treatments $(1.5 \mathrm{~mL}$ of each treated diet) were placed in Elisa plates $\left(\mathrm{TPP}^{\circledR}\right.$ Techno Plastic Products AG, Trasadingen, Canton Schaffhausen, Switzerland) using a micropipettor. Twenty-four hours after the addition, each cell was infested with neonate $H$. armigera larvae (Talekar et. 2006; Tolosa et al. 2014). Six replicates were used for each treatment, and each replicate was one plate $(n=144)$. Larval mortality rates were quantified daily for 7 days.

\section{Concentration-response curves of active extracts}

Based on the results from the screening, the most promising treatment (ethanolic seed extract from A. mucosa) and the acetogenin-based commercial bioinsecticide (Anosom ${ }^{\circledR} 1$ EC) were evaluated again to estimate the $\mathrm{LC}_{50}$ and $\mathrm{LC}_{90}$ (the concentrations required to kill 50 and 90 percent of exposed caterpillars, respectively) and the $\mathrm{EC}_{50}$ (the concentration required to reduce the larval weight by $50 \%$ ). Therefore, five concentrations were defined for each concentration (range 0-2000 ppm), based on Finney (1971) procedure.

The experimental procedures were identical to those used in the screening tests. Four replicates were used for each treatment, and each replicate consisted of a single plate $(n=96)$.

\section{Average lethal time $\left(\mathbf{L} \mathbf{T}_{\mathbf{5 0}}\right)$}

The $\mathrm{LT}_{50}$ values (the time required to kill $50 \%$ of test population) for the Anosom ${ }^{\circledR} 1 \mathrm{EC}$ and ethanolic extract from A. тисоsa seeds (most promising extract) were 
estimated at concentrations of 1000 and $2000 \mathrm{ppm}$. The experimental procedures were identical to those used in the screening tests.

\section{Isolation of and bioassay with the primary acetogenin in the selected seed extract}

Chromatographic procedures were used to purify and isolate the primary acetogenin in the ethanolic extract from $A$. mисоsa seeds. For this purpose, we used various chromatography techniques, which included adsorption chromatography on an analytical thin layer (ADCC) using aluminum sheet silica gel $60 \mathrm{~F}_{254} 0.2 \mathrm{~mm}$ thick, adsorption column chromatography (CC) using as stationary phase silica gel 70-230 mesh and 230-400 mesh, and high-performance liquid chromatography (HPLC). For HPLC, a gas chromatograph model 1200 (Agilent Technologies) equipped with quaternary pump G1311A, degasser G1322A, automatic sampler G1329A and ultraviolet detector G1314B was used. The equipment was coupled to an interface G1369A, and the chromatograms were recorded by EZCrom Ellite software. The stationary phase was a reversed phase Phenomenex Luna C-18 for analytic $(10$ micrometers, $25.0 \times 0.46 \mathrm{~cm})$ and preparative $(10$ micrometers, $25.0 \times 1.0 \mathrm{~cm})$ purposes with a recycle valve and $200 \mu \mathrm{L}$ loop.

The characterization of the isolated compound was conducted by spectroscopic techniques [dimensional $\left({ }^{1} \mathrm{H}\right.$ NMR and ${ }^{13} \mathrm{C}$ ) and two-dimensional (COSY, HSQC, HMBC) nuclear magnetic resonance] and by mass spectrometry. For these characterizations, spectrometers Bruker Avance III NanoBay 9,4T (400 MHz for ${ }^{1} \mathrm{H}$ NMR and $100 \mathrm{MHz}$ for ${ }^{13} \mathrm{C}$ NMR) and Micromass Quattro LC, with methods for direct insertion and ionization mode to capture electrons (negative mode), were used.

To evaluate the insecticidal effect of the isolated acetogenin against $H$. armigera, we used a concentration equivalent to $10 \%$ of the estimated $\mathrm{LC}_{50}$ value for the respective seed ethanol-extract. The experimental procedures were identical to those used in the screening tests. Four replicates were used for each treatment, and each replicate was one plate $(n=80)$.

\section{Bioactivity of selected extracts compared with a commercial insecticide and acetogenin-based commercial bioinsecticide in greenhouse trials}

To evaluate the efficacy of the most promising extract and Anosom ${ }^{\circledR} 1 \mathrm{EC}$, under greenhouse conditions, a test was performed using a commercial insecticide based on flubendiamide $\left(\right.$ Belt $^{\circledR} 480$ SC, Bayer Corporation, Dormagen, Germany) as a positive control. The insecticide Belt $^{\circledR} 480 \mathrm{SC}$ was used at the dose recommended by the manufacturer (416.7 ppm), whereas the ethanolic extract from A. mucosa seeds and the Anosom ${ }^{\circledR} 1 \mathrm{EC}$ were used at the $\mathrm{LC}_{90}$ values (1479 and $1151 \mathrm{ppm}$, respectively) estimated previously. For preparation of aqueous emulsified formulation, the A. mucosa ethanolic seed extract was solubilized in the organic solvents acetone/methanol (1:1, $\mathrm{v} / \mathrm{v})\left(100 \mathrm{~g} \mathrm{~L}^{-1}\right)$, with the subsequent addition of Tween ${ }^{\circledR}$ 80 emulsifier at a concentration of $10 \mathrm{~g} \mathrm{~L}^{-1}$.

The test was conducted on tomato plants 30-45 days old. Each plant was planted in a 2.5 -L pot containing soil and commercial substrate $\left(\right.$ Plantmax $\left.^{\circledR}\right)$ mixed at a ratio of 3:1 (v/v). The treatments were applied to plants with a gravity-type spray gun (Model Arprex 5A), coupled to an air compressor set to provide a pressure of $0.5 \mathrm{kgf} \mathrm{cm}^{-2}$. The plants were sprayed until the point of runoff, and after the residues dried, a leaf from each plant was artificially infested with 10 neonate $H$. armigera larvae. Subsequently, a "voile" cage was placed on the leaves to prevent insect escape. Ten replicates were used for each treatment, and each replicate was one plant $(n=100)$.

The infested leaf remained on countertops in a greenhouse. After 6 days of infestation, mortality and weight of the surviving larvae were determined. Larvae were considered dead when there was no reaction (movement) after a light touch with a fine brush.

\section{Data analyses}

Generalized linear models of the exponential family of distributions (Nelder and Wedderbum 1972) were used for the analyses of studied variables. The verification of quality adjustment was performed through the half-regular graph odds with simulation envelope (Demétrio and Hinde 1997; Hinde and Demétrio 1998). When there were significant differences among treatments, multiple comparisons (Tukey's test, $p<0.05$ ) were performed using the glht function by means of Multicomp package, with adjustment of $p$ values. All analyses were performed using the " $\mathrm{R}$ " statistical software version 2.15.1 (R Development Core Team 2012).

A binomial model with a complementary log-log link function (gompit model) was used to estimate the lethal concentrations $\left(\mathrm{LC}_{50}\right.$ and $\mathrm{LC}_{90}$ ), using the Probit Procedure in the software SAS version 9.2 (SAS Institute 2011). Finally, the mean lethal time $\left(\mathrm{LT}_{50}\right)$ was estimated using the method proposed by Throne et al. (1995) for Probit analysis of correlated data.

\section{Results}

\section{Extraction yield}

The extraction yield varied significantly (11-27.85\%), depending on the species (Table 2). The highest yield was 
Table 2 Yields of extracts obtained by maceration of seeds in ethanol $(1: 5, w / v)$ from the five species of Neotropical Annonaceae

\begin{tabular}{lcll}
\hline Species & Material weight $(\mathrm{g})$ & \multicolumn{2}{l}{ Yield } \\
\cline { 3 - 4 } & & $(\mathrm{g})$ & $(\%)$ \\
\hline Annona montana & 95.60 & 19.34 & 20.23 \\
Annona mucosa & 106.21 & 19.95 & 18.79 \\
Annona muricata & 104.50 & 22.06 & 21.10 \\
Annona reticulata & 100.00 & 27.85 & 27.85 \\
Annona sylvatica & 100.00 & 11.00 & 11.00 \\
\hline
\end{tabular}

obtained from seeds of $A$. reticulata and the lowest from seeds of A. sylvatica.

\section{Laboratory bioassays}

Significant differences were detected among the treatments tested at $2000 \mathrm{ppm}$ in the initial screening (Table 3). After $168 \mathrm{~h}$ of exposure (bioassay endpoint), Anosom ${ }^{\circledR} 1 \mathrm{EC}$ $\left[\mathrm{LC}_{50}=312.08 \mathrm{ppm}\right.$; Table 4] and the A. mucosa seed extract $\left[\mathrm{LC}_{50}=411.55 \mathrm{ppm}\right.$; Table 4] were the most promising treatments, resulting in total mortality of exposed larvae (Table 3 ). The effect of seed extracts from A. reticulata, A. montana and $A$. muricata on larvae was different from that of the control (Table 3), but the effects were much less pronounced than those of the more active treatments.

The average lethal time $\left(\mathrm{LT}_{50}\right)$ estimated for the most active treatment varied according to the concentration tested and was $45.15 \mathrm{~h}(95 \% \mathrm{CI}=7.66-88.40 \mathrm{~h} ; \chi=11.23$; g.l. $=4 ; n=672)$ and $34.95 \mathrm{~h}(95 \% \mathrm{CI}=27.54-41.63 \mathrm{~h}$; $\chi=6.87$; g.l. $=4 ; n=672$ ) for A. mucosa ethanolic seed extract at concentrations of 1000 and 2000 ppm, respectively. For Anosom ${ }^{\circledR}$ the estimated average lethal times were $47.69 \mathrm{~h}(95 \% \mathrm{CI}=18.51-76.22 ; \chi=10.19 ;$ g.l. $=4$; $n=672)$ and $39.78 \mathrm{~h}(95 \% \mathrm{CI}=18.42-56.20 ; \chi=17.52$; g.l. $=4 ; n=672$ ) for concentrations of 1000 and $2000 \mathrm{ppm}$, respectively.

In addition to acute effects, Anosom ${ }^{\circledR}\left[\mathrm{EC}_{50}=173.60\right.$ ppm $(95 \% \mathrm{CI}=56.82-290.40 \mathrm{ppm} ; n=324)]$ and $A$. mисоsa ethanolic seed extract $\left[\mathrm{EC}_{50}=239.00 \mathrm{ppm}(95 \%\right.$ $\mathrm{CI}=129.10-348.00 \mathrm{ppm} ; n=367)]$ significantly inhibited $H$. armigera larval development. However, the difference between these treatments was not significant based on the comparison of the confidence intervals of the adjusted values.

Using different chromatography techniques, the primary compound of the A. mucosa ethanolic seed extract was isolated and then was identified as acetogenin bis-tetrahydrofuran rolliniastatin-1 (Fig. 1) using spectroscopic and spectrometric techniques. The isolated acetogenin increased the larval mortality after $48 \mathrm{~h}$ of exposure, and total mortality was observed after $120 \mathrm{~h}$ of exposure (Table 5).

\section{Greenhouse trial}

Larval mortality exceeded $90 \%$ with exposure to A. тисовa ethanolic seed extract and the Anosom ${ }^{\circledR} 1$ EC (Table 6).Total mortality of larvae was observed with the

Table 3 Accumulated mortality $( \pm \mathrm{SE})$ of Helicoverpa armigera caterpillars exposed to artificial diet treated (2000 ppm) with various derivatives of Annonaceae

\begin{tabular}{|c|c|c|c|c|}
\hline \multirow[t]{2}{*}{ Treatments } & \multicolumn{4}{|c|}{ Exposure time $(\mathrm{h})^{1}$} \\
\hline & 24 & 72 & 120 & 168 \\
\hline E.E.S. Annona reticulata & $4.35 \pm 2.20$ & $27.66 \pm 3.16$ & $29.11 \pm 2.96$ & $29.36 \pm 3.02$ \\
\hline E.E.S. Annona mucosa & $31.55 \pm 5.08$ & $100.00 \pm 0.00 *$ & $100.00 \pm 0.00^{*}$ & $100.00 \pm 0.00^{*}$ \\
\hline E.E.S. Annona montana & $0.00 \pm 0.00^{*}$ & $21.55 \pm 3.04$ & $24.62 \pm 3.30$ & $24.62 \pm 3.30$ \\
\hline E.E.S. Annona muricata & $6.05 \pm 2.32$ & $35.77 \pm 2.88$ & $35.77 \pm 2.88$ & $35.77 \pm 2.88$ \\
\hline E.E.S. Annona sylvatica & $0.69 \pm 0.69$ & $7.01 \pm 2.03$ & $7.01 \pm 2.03$ & $7.01 \pm 2.03$ \\
\hline Anosom $^{\circledR} 1 \mathrm{EC}$ & $97.92 \pm 1.42$ & $100.00 \pm 0.00 *$ & $100.00 \pm 0.00^{*}$ & $100.00 \pm 0.00 *$ \\
\hline Control (water) & $0.00 \pm 0.00^{*}$ & $0.72 \pm 0.72$ & $1.42 \pm 0.90$ & $2.14 \pm 1.47$ \\
\hline \multirow[t]{2}{*}{ Control (Acet/meth, 1:1) } & $2.17 \pm 1.48$ & $2.84 \pm 1.79$ & $2.84 \pm 1.79$ & $2.84 \pm 1.79$ \\
\hline & $\begin{array}{c}F_{5.30}=81.827 \\
p<0.0001\end{array}$ & $\begin{array}{c}F_{5.30}=27.507 \\
p<0.0001\end{array}$ & $\begin{array}{c}F_{5.30}=29.588 \\
p<0.0001\end{array}$ & $\begin{array}{c}F_{5.30}=25.398 \\
p<0.0001\end{array}$ \\
\hline
\end{tabular}

E.E.S. Seed ethanol-extract

* Not included in the statistical analysis (null variance)

${ }^{1}$ Means followed by different letters within a column indicate significant differences among treatments (GLM with quasi-binomial distribution, followed by post hoc Tukey's test, $p<0.05$ ) 
Table 4 Estimates of $\mathrm{LC}_{50}$ and $\mathrm{LC}_{90}(\mathrm{ppm})$ with confidence intervals for the acetogenin-based commercial bioinsecticide (Anosom $\left.{ }^{\circledR} 1 \mathrm{EC}\right)$ and Annona тисоsa ethanolic seed extract-ESAM (Annonaceae) on Helicoverpa armigera caterpillars after $168 \mathrm{~h}$ of exposure

\begin{tabular}{|c|c|c|c|c|c|c|c|}
\hline Treatments & $\mathrm{n}$ & Slope \pm EP ( $p$ value $)$ & $\mathrm{LC}_{50}(\mathrm{CI})$ & $\mathrm{LC}_{90}(\mathrm{CI})$ & $\chi^{2}$ & d.f. & h. \\
\hline Anosom $^{\circledR}$ & 672 & $2.11 \pm 0.21(p<0.0001)$ & $312.08(244.00-377.45)$ & $1151.00(956.83-1457.00)$ & 4.69 & 3 & 1.56 \\
\hline ESAM & 672 & $2.16 \pm 0.37(p<0.0001)$ & 411.55 (185.07-609.85) & $1479.00(1011.00-3069.00)$ & 9.18 & 4 & 2.29 \\
\hline
\end{tabular}

$n$ number of insects tested

CI confidence interval at $95 \%$ error probability

$\chi^{2}$ Pearson's Chi-square value

$d f$ degrees of freedom

$h$ heterogeneity factor<smiles>CCCC[C@H](O)[C@@H]1CCC(C2CCC([C@@H](O)CNC(O)CC3=CC(C)OC3=O)O2)O1</smiles>

Fig. 1 Chemical structure of acetogenin rolliniastatin-1, the primary compound of the ethanol extract of Annona mисоsa seeds (ESAM)

flubendiamide-based commercial insecticide $\left(\right.$ Belt $^{\circledR} 480$ SC) (Table 6) during the exposure period.

In addition to high mortality rates, the average weight of surviving larvae was significantly reduced (Table 6), which confirmed that these derivatives of Annonaceae inhibit larval development, an effect previously detected in laboratory tests.

\section{Discussion}

The public awareness of the negative impacts on the environment and human health of the use of synthetic insecticides is founded (Isman and Grieneisen 2014). The widespread use of conventional insecticides and their negative effects on human health have stimulated the increase in botanical insecticide research as well as the identification of plant-derived compounds with insecticidal activity (Castillo-Sánchez et al. 2010; Baldin et al. 2015; Tak et al. 2016). Our bioassays presented the ethanolic extract from seeds of $A$. mucosa (ESAM) as a promising tool in pest management. ESAM produced $100 \%$ larval mortality, and its activity was comparable to flubendiamide and acetogenin-based insecticides under laboratory and greenhouse conditions. The high insecticidal activity of ESAM was also observed on $S$. frugiperda larvae where its efficiency was similar to a chlorantraniliprole-based insecticide and authors suggest their potential use in small farms due to simplicity of preparation (Ansante et al. 2015). The bioactivity of crude extracts is related to the interaction of different compounds which form complex mixtures (Isman 2000). ESAM bioactivity is associated with presence of alkaloids, triglycerides and especially acetogenins as well as synergistic interaction between these chemical compounds (Ribeiro et al. 2014c; Ansante et al. 2015).

Table 5 Cumulative mortality ( $\% \pm \mathrm{SE}$ ) of Helicoverpa armigera caterpillars exposed to an artificial diet containing the acetogenin bistetrahydrofuran rolliniastatin-1 $(41.55 \mathrm{ppm})$ at different times of exposure

\begin{tabular}{|c|c|c|c|c|c|}
\hline \multirow[t]{2}{*}{ Treatment } & \multicolumn{5}{|c|}{ Exposure time $(h)^{1}$} \\
\hline & 24 & 48 & 72 & 96 & 120 \\
\hline Rolliniastatin-1 & $0.00 \pm 0.00^{*}$ & $28.75 \pm 3.75$ & $61.25 \pm 4.27$ & $92.50 \pm 3.23$ & $100.00 \pm 0.00^{*}$ \\
\hline Control (acetone) & $0.00 \pm 0.00^{*}$ & $1.25 \pm 1.25$ & $2.50 \pm 1.44$ & $2.50 \pm 1.44$ & $2.50 \pm 1.44$ \\
\hline \multirow[t]{2}{*}{ Control (deionized water) } & $0.00 \pm 0.00^{*}$ & $1.25 \pm 1.25$ & $1.25 \pm 1.25$ & $1.25 \pm 1.25$ & $1.25 \pm 1.25$ \\
\hline & - & $\begin{array}{c}F_{2.9}=24.99 \\
p<0.0001\end{array}$ & $\begin{array}{c}F_{2.9}=74.387 \\
p<0.0001\end{array}$ & $\begin{array}{c}F_{2.9}=118.61 \\
p<0.0001\end{array}$ & $\begin{array}{c}F_{1.6}=0,4081 \\
p<0,5465\end{array}$ \\
\hline
\end{tabular}

$n s$ not significant

* Not included in the analysis (null variance)

${ }^{1}$ Means followed by different letters within a column indicate significant differences among treatments (GLM with quasi-binomial distribution, followed by post hoc Tukey's test, $p<0.05$ ) 
Table 6 Efficacy of formulated ethanolic extract from Annona mucosa seeds and an acetogenin-based (Anosom ${ }^{\circledR} 1$ EC) and flubendiamidebased (Belt ${ }^{\circledR} 480 \mathrm{SC}$ ) commercial insecticides against Helicoverpa armigera in a greenhouse trial

\begin{tabular}{|c|c|c|c|c|}
\hline Treatments & $\begin{array}{l}\text { Concentration } \\
(\mathrm{ppm})\end{array}$ & $\begin{array}{l}\text { Mortality } \\
\text { Mean } \pm \text { SE }\end{array}$ & $\begin{array}{l}\text { Corrected } \\
\text { mortality }^{2}\end{array}$ & $\begin{array}{l}\text { Larval weight } \\
(\mathrm{mg})^{*}\end{array}$ \\
\hline ESAM $^{3}$ & 1479.0 & $95.00 \pm 2.23$ & 94.68 & $0.4875(5)$ \\
\hline Anosom $^{\circledR} 1 \mathrm{EC}$ & 1151.0 & $93.00 \pm 2.60$ & 94.16 & $0.82(7)$ \\
\hline$\left(\mathrm{Belt}^{\circledR} 480 \mathrm{SC}\right)$ & 416.7 & $100.00 \pm 0.00^{*}$ & 100.00 & - \\
\hline Control (deionized water) & & $4.44 \pm 1.75$ & - & $5.14 \pm 0.05$ \\
\hline \multirow{2}{*}{$\begin{array}{l}\text { Control (methanol/water, } 1: 10(\mathrm{v} / \mathrm{v})+\text { Tween } 80^{\circledR} \text {, } \\
0.5 \%\end{array}$} & & $6.00 \pm 2.21$ & - & $5.01 \pm 0.15$ \\
\hline & & \multicolumn{3}{|c|}{$F_{3.36}=113.25 ; p<0.0001$} \\
\hline \multicolumn{5}{|c|}{ * Data not analyzed because of small sample size. The value in parentheses represents the number of surviving caterpillars in those treatments } \\
\hline \multirow{2}{*}{\multicolumn{5}{|c|}{$\begin{array}{l}1 \text { Means followed by different letters within a column indicate significant differences among treatments (GLM with quasi-binomial distribution, } \\
\text { followed by post hoc Tukey's test, } p<0.05 \text { ) }\end{array}$}} \\
\hline & & & & \\
\hline \multicolumn{5}{|c|}{2 Corrected mortality calculated using the formula of Abbott (1925) } \\
\hline \multicolumn{5}{|l|}{3 ESAM Annona mucosa seed ethanol-extract } \\
\hline
\end{tabular}

The potential insecticidal properties of Annonaceae crude extract species for the control of other lepidopteran pests of horticultural crops have been highlighted in recent studies. For example, the activity of A. muricata leaf-extract on cabbage leaves, at concentration of $5000 \mathrm{ppm}$ causes $100 \%$ mortality of $P$. xylostella larvae (Trindade et al. 2006). Similarly, an ethanol extract of $A$. squamosa seeds applied to cabbage showed greater efficacy against $P$. xylostella than a rotenone-based or pyrethrin-based commercial insecticides (Leatemia and Isman 2004). Studies with four species of Annona (A. montana, A. mucosa, A. muricata and $A$. sylvatica), which were also investigated in our study, and the acetogenin-based commercial bioinsecticide found significant insecticidal activity on third instar T. $n i$ larvae. The A. mucosa extract (ESAM) and the acetogenin-based commercial bioinsecticide cause high $T . n i$ larval mortality (98\%) after $120 \mathrm{~h}$ on cabbage leaves in a greenhouse trial, showing higher efficiency than that of a pyrethrin-based commercial insecticide (Insect Spray ${ }^{\circledR}$ ). In our study, the mortality caused by ESAM extract and acetogenin-based commercial bioinsecticide was higher $(100 \%)$ than that observed by those authors; however, we used neonate $H$. armigera larvae, which were likely more sensitive to the compounds than third instar $T$. ni larvae (Ribeiro et al. 2014a).

The chromatographic separation techniques mediated bioguided trials (Ansante et al. 2015) identified the acetogenin bis-tetrahydrofuran rolliniastatin-1 as the primary active component from ESAM. The toxic effect of nine acetogenins mono- and bis-tetrahydrofuran derived from $A$. cherimolia was evaluated on $S$. frugiperda and was observed that major acetogenin bis-tetrahydrofuran squamocin (annonin) was the most effective (Colom 2007). The promising ESAM activity reported in our study is probably related to its major compound rolliniastatin-1 that is composed of two tetrahydrofuran rings possessing no-adjacent in chain. Numbers of tetrahydrofuran rings in chain can be decisive in acetogenin larvae toxicity where bistetrahydrofuran can be twice stronger than mono-tetrahydrofuran (Blessing et al. 2010). Some published studies have shown the position of tetrahydrofuran rings in chain can be also related to acetogenin toxicity (Colom et al. 2007; He et al. 1997). Acetogenins are potent inhibitors of complex I (NADH: ubiquinone oxidoreductase) of the mitochondrial electron-transport system and of the coenzyme NADH in the cell membranes of target arthropods (Lewis et al. 1993). However, based on more recent studies, the variability of biological effects and the different functional groups in the form of compound chains indicate that inhibition of the mitochondrial complex is likely not the only mode of action of acetogenins (Blessing et al. 2012; Ribeiro et al. 2013).

The toxicity of six mono-tetrahydrofuran acetogenins isolated from A. montana on S. frugiperda was evaluated with exposure in artificial diet (100 ppm) and observed $100 \%$ mortality (larval and pupal stages) in some treatments. The authors identified annonacin, cis-annonacin10-one and gigantetronenin, which cause high larval mortality $(50 \%)$, as the most promising acetogenins (Blessing et al. 2010). Acetogenin bis-tetrahydrofuran rolliniastatin-1 from ESAM, that was tested at concentration of $84 \mathrm{ppm}$, causes 90 and $100 \%$ mortality of $S$. frugiperda larvae after seven days of exposure in treated artificial diet (Ansante et al. 2015). In the present study, after 5 days of exposure, total mortality of $H$. armigera larvae occurred at a concentration of $41.55 \mathrm{ppm}(10 \%$ $\mathrm{LC}_{50}$ ), with these larvae showing greater susceptibility than those of $S$. frugiperda. 
$H$. armigera was recently introduced into Brazil and synthetic insecticides are registered for temporary use, and therefore, the use of botanical insecticides provides an alternative control measure for implementation within an integrated pest management (IPM) program, particularly for organic systems of vegetable crops such as tomato. Although the development of formulations involving products of botanical origin still faces challenges, such as increasing the stability, the use of $A$. mucosa ethanolic seed extract (ESAM) appears to be promising because the product is easy to obtain (maceration in ethanol) at a low cost and is harmless to plants (no phytotoxicity). The efficacy of this extract was comparable with that of the acetogeninbased commercial bioinsecticide and the flubendiamidebased commercial insecticide in semi-field trial, with the latter on record for emergency use in Brazil to control this pest. These results confirmed the potential of $A$. тисоsa extracts as an alternative control measure for this important agricultural pest, which corroborates previously obtained results (Ribeiro et al. 2013, 2014a, b, c; Ansante et al. 2015) and expands the spectrum of action for the derivatives from this species of Annonaceae native to Brazil.

\section{Authors' contribution}

ELLB, LPR, CMS and JDV conceived and designed the research. CMS, RM and IFS conducted the experiments. JBF and KUB performed the chemical analysis. LPR analyzed the data. CMS, ELLB and LPR wrote the manuscript.

Acknowledgements Funding for research was provided by Coordination for the Improvement of Higher Education Personnel.

\section{Compliance with ethical standards}

Conflict of interest All authors declare that they have no conflict of interest.

Ethical approval This article does not contain any studies with human or animal performed by any of the authors.

\section{References}

Aheer GM, Shah Z, Saeed M (2009) Seasonal history and biology of cotton mealy bug, Phenacoccus solenopsis Tinsley. J Agric Res 47:4

Alali FQ, Liu XX, McLaughlin JL (1999) Annonaceous acetogenins: recent progress. J Nat Prod 62:504-540. doi:10.1021/np980406d

Ansante TF, Ribeiro LP, Bicalho KU, Fernandes JB, Silva MFGF, Vieira PC, Vendramim JD (2015) Secondary metabolites from Neotropical Annonaceae: screening, bioguided fractionation, and toxicity to Spodoptera frugiperda (JE Smith)(Lepidoptera: Noctuidae). Ind Crops Prod 74:969-976. doi:10.1016/j.indcrop. 2015.05.058
Baldin ELL, Aguiar GP, Fanela TL, Soares MC, Groppo M, Crotti AE (2015) Bioactivity of Pelargonium graveolens essential oil and related monoterpenoids against sweet potato whitefly, Bemisia tabaci biotype B. J Pest Sci 88:191-199. doi:10.1007/ s10340-014-0580-8

Blessing LT, Colom OA, Popich S, Neske A, Bardón A (2010) Antifeedant and toxic effects of acetogenins from Annona montana on Spodoptera frugiperda. J Pest Sci 83:307-310. doi:10.1007/s10340-010-0299-0

Blessing LD, Ramos J, Diaz S, Ben AA, Bardón A, Brovetto M, Neske A (2012) Insecticidal properties of annonaceous acetogenins and their analogues. Interaction with lipid membranes. Nat Prod Commun 7:1215-1218. doi:10.1021/bi9723481

Bueno AF, Sosa-Gómez DR (2014) The old world bollworm in the Neotropical region: the experience of Brazilian growers with Helicoverpa armigera. Outlook Pest Manag 25:261-264. doi:10. 1564/v25_aug_04

Bueno RCOF, Yamamoto PT, Carvalho MM, Bueno NM (2014) Occurrence of Helicoverpa armigera (Hübner, 1808) on citrus in the state of Sao Paulo, Brazil. Rev Bras Frutic 36:520-523. doi:10.1590/0100-2945-357/13

Castillo-Sánchez LE, Jiménez JJ, Delgado MA (2010) Secondary metabolites of the Annonaceae, Solanaceae and Meliaceae families used as biological control of insects. Trop Subtrop Agric J 12:445-462

Chatrou LW, Rainer H, Maas PJM (2004) Annonaceae (Soursop family). In: Smith N (ed) Flowering plants of the neotropics. Botanical Garden, New York, pp 18-20

Cloyd R (2004) Natural indeed: are natural insecticide safer and better than conventional insecticide? Ill Pestic Rev 17:1-3

Colom OÁ, Neske A, Popich S, Bardón A (2007) Toxic effects of annonaceous acetogenins from Annona cherimolia (Magnoliales: Annonaceae) on Spodoptera frugiperda (Lepidoptera: Noctuidae). J Pest Sci 80:63-67. doi:10.1007/s10340-006-0149-2

Czepak C, Albernaz KC, Vivan LM, Guimarães HO, Carvalhais T (2013) Primeiro registro de ocorrência de Helicoverpa armigera (Hübner) (Lepidoptera: Noctuidae) no Brasil. Pesqui Agropecu Trop 43:110-113. doi:10.1590/S1983-40632013000100015

Demétrio CGB, Hinde J (1997) Half-normal plots and overdispersion. Glim Newsl 27:19-26

Finney DJ (1971) Probit analysis. Cambridge University Press, Cambridge

Gonçalves GLP, Ribeiro LP, Gimenes L, Vieira PC, Silva MFGF, Forim MR, Vendramim JD (2015) Lethal and sublethal toxicities of Annona sylvatica (Magnoliales: Annonaceae) extracts to Zabrotes subfasciatus (Coleoptera: Chrysomelidae: Bruchinae). Fla Entomol 98:921-928. doi:10.1653/024.098.0317

Greene GL, Leppla NC, Dickerson WA (1976) Velvetbean caterpillar: a rearing procedure and artificial medium. J Econ Entomol. doi:10.1093/jee/69.4.487487-488

He H, Zeng L, Ye Q, Shi G, Oberlies N, Zhao G, Njoku C, Mclaughlin J (1997) Comparative SAR evaluations of annonaceous acetogenins for pesticidal acitivity. Pestic Sci 49:372-378. doi:10.1002/(SICI)10969063(199704)49:4<372:AID-PS543>3. $0 . \mathrm{CO} ; 2-\mathrm{K}$

Hinde J, Demétrio CGB (1998) Overdispersion: models and estimation. Comput Stat Data Anal 27:151-170. doi:10.1016/S01679473(98)00007-3

Isman MB (2000) Plant essential oils for pest and disease management. Crop Prot 19:603-608. doi:10.1016/S0261-2194(00)00079-X

Isman MB (2006) Botanical insecticides, deterrents, and repellents in modern agriculture and an increasingly regulated world. Annu Rev Entomol 51:45-66. doi:10.1146/annurev.ento.51.110104.151146

Isman MB, Grieneisen ML (2014) Botanical insecticide research: many publications, limited useful data. Trends Plant Sci 19:140-145. doi:10.1016/j.tplants.2013.11.005 
Isman MB, Seffrin R (2014) Natural insecticides from the Annonaceae: a unique example for developing biopesticides. In: D Singh (ed) Advances in plant biopesticides. Springer, New Delhi, pp 21-33. doi: 10.1007/978-81.322-2006-0_2

Jah RK, Chi H, Tang LC (2012) A comparison of artificial diet and hybrid sweet corn for the rearing of Helicoverpa armigera (Hübner) (Lepidoptera: Noctuidae) based on life table characteristics. Environ Entomol 41:30-39. doi:10.1603/EN11206

Jouben N, Agnolet S, Lorenz S, Schöne SE, Ellinger R, Schneider B, Heckel DG (2012) Resistance of Australian Helicoverpa armigera to fenvalerate is due to the chimeric P450 enzyme CYP337B3. Proc Nat Acad Sci U.S.A. 109:15206-15211. doi:10.1073/pnas.1202047109

Kao SS (1995) Mass rearing of insects. Bulletin of Taiwan Agricultural Chemicals and Toxic Substances Research Institute (TACTRI) 37:1-8

Lammers JW, Macleod A (2007) Report of a pest risk analysis: Helicoverpa armigera (Hübner, 1808). http://www.fera.defra. gov.uk/plants/ plantHealth/pestsDiseases/documents/helicoverpa.pdf. Accessed on 5 Oct 2014

Leatemia JA, Isman MB (2004) Efficacy of crude seed extracts of Annona squamosa against diamondback moth, Plutella xylostella $\mathrm{L}$. in the greenhouse. Int J Pest Manage 50:129-133. doi:10. 1080/096708704100001691821

Lewis MA, Arnason JT, Philogene BJR, Rupprecht JK, Mclaughlin JL (1993) Inhibition of respiration at site I by asimicin, an insecticidal acetogenin of the pawpaw, Asimina triloba (Annonaceae). Pestic Biochem Physiol 45:15-23. doi:10.1006/pest. 1993.1003

Murúa MG, Scalora FS, Navarro FR, Cazado LE, Casmuz A, Villagrán ME, Lobos E, Gastaminza G (2014) First record of Helicoverpa armigera (Lepidoptera: Noctuidae) in Argentina. Fla Entomol 97:854-856. doi:10.1653/024.097.0279

Nelder JA, Wedderburn RWM (1972) Generalized linear models. J R Stat Sci 135:370-384. doi:10.2307/2344614

Ocampo D, Ocampo R (2006) Bioactividad de la familia Annonaceae. Rev Univ Caldas 1:135-155

R Development Core Team (2012) R: a language and environment for statistical computing. R foundation for statistical computing, Vienna, pp 73-80

Ribeiro LP, Vendramim JD, Bicalho KU, Andrade MS, Fernandes JB, Moral RA, Demétrio CGB (2013) Annona mucosa Jacq. (Annonaceae): a promising source of bioactive compounds against Sitophilus zeamais Mots. (Coleoptera: Curculionidae). J Stored Prod Res 55:6-14. doi:10.1016/j.jspr.2013.06.001

Ribeiro LP, Akhtar Y, Vendramim JD, Isman MB (2014a) Comparative bioactivity of selected seed extracts from Brazilian Annona species and an acetogenin-based commercial bioinsecticide against Trichoplusia $n i$ and Myzus persicae. Crop Prot 62:100-106. doi:10.1016/j.cropro.2014.04.013

Ribeiro LP, Vendramim JD, Andrade MS, Bicalho KU, Silva MFGF, Vieira PC, Fernandes JB (2014b) Tropical plant extracts as sources of grain-protectant compounds against Sitophilus zeamais Motschulsky (Coleoptera: Curculionidae). Neotrop Entomol 43:470-482. doi:10.1007/s13744-014-0233-x
Ribeiro LP, Zanardi OZ, Vendramim JD, Yamamoto PT (2014c) Comparative toxicity of an acetogenin-based extract and commercial pesticides against citrus red mite. Exp Appl Acarol 64:87-98. doi:10.1007/s10493-014-9810-2

Ribeiro LP, Santos MS, Gonçalves GLP, Vendramim JD (2015) Toxicity of an acetogenin-based bioinsecticide against $\mathrm{Di}$ aphorina citri (Hemiptera: Liviidae) and its parasitoid Tamarixia radiata (Hymenoptera: Eulophidae). Fla Entomol 98:835-842. doi:10.1653/024.098.0304

SAS Institute (2011) Statistical analysis system: getting started with the SAS learning. Version 9.2. NC: SAS Institute

Specht A, Gomez DR, Paula-Moraes SV, Yano SA (2013) Morphological and molecular identification of Helicoverpa armigera (Lepidoptera: Noctuidae) and expansion of its occurrence record in Brazil. Pesqui Agropecu Bras 48:689-692. doi:10.1590/ S0100-204X2013000600015

Tak JH, Jovel E, Isman MB (2016) Contact, fumigant, and cytotoxic activities of thyme and lemongrass essential oils against larvae and an ovarian cell line of the cabbage looper, Trichoplusia ni. J Pest Sci 89:183-193. doi:10.1007/s10340-015-0655-1

Talekar NS, Opena RT, Hanson P (2006) Helicoverpa armigera management: a review of AVRDC's research on host plant resistance in tomato. Crop Prot 25:461-467. doi:10.1016/j. cropro.2005.07.011

Throne JE, Weaver DK, Chew VB, James E (1995) Probit analysis of correlated data: multiple observations over time at one concentration. J Econ Entomol 88:1510-1512. doi:10.1093/jee/88.5. 1510

Tolosa D, Hidalgo JR, Sal PE, Popich S, Bardón A, Neske A (2014) Insecticidal effects of the Annonaceous acetogenin squamocin and the acetogenin fraction of seeds of Rollinia occidentalis on soybean and corn pests. J Agric Food Chem 3:156-160. doi:10. 1007/s10340-006-0149-2

Trindade RCP, Luna JS, Lima MRF, Silva PP, Santana AEG (2006) Actividad larvicida y variacion estacional del extracto de Annona muricata en Plutella xylostella (Lepidoptera: Plutellidae). Rev Colomb Entomol 3:223-228

Venette RC, Davis EE, Zaspel Z, Heisler H, Larson M (2003) Mini risk assessment, old world bollworm, Helicoverpa armigera (Hübner) (Lepidoptera: Noctuidae). US department of agriculture, animal and plant health inspection service. http://www. aphis.usda.gov/plant_health/plant_pest_info/pest_detection/do wnloads/pra/harmigerapra.pdf. Accessed 8 Apr 2013

Yang Y, Li Y, Wu Y (2013) Current status of insecticide resistance in Helicoverpa armigera after 15 years of $B t$ cotton planting in China. J Econ Entomol 106:375-381. doi:10.1603/EC12286

Zanardi OZ, Ribeiro LP, Ansante TF, Santos MS, Bordini GP, Yamamoto PT, Vendramim JD (2015) Bioactivity of a matrinebased biopesticide against four pest species of agricultural importance. Crop Prot 67:160-167. doi:10.1016/j.cropro.2014. 10.010

Zhang H, Yin W, Zhao J, Jin L, Yang Y, Wu S, Tabashnik BE, Wu Y (2011) Early warning of cotton bollworm resistance associated with intensive planting of $B t$ cotton in China. PLoS ONE 6:22874. doi:10.1371/journal.pone.0022874 